\title{
Management practices followed by milk producers in Pune district
}

P.L. KOLEKAR, N.H. GORE AND J.V. LEMBHE

Received : $31.08 .2017 ;$ Accepted : 30.09.2017

\begin{abstract}
Data pertained to the year 2010-2011 in order to study management practices followed by milk producers in Pune district of Maharashtra. Frequency and percentage was used to analyze management practices followed by milk producers. Results revealed that feeding of cows was major management practice which was expressed by 100.00 per cent. Breeding and dryingoff-a cow were next major management practices followed in dairy unit which was expressed by 97.91 per cent. Cleaning, washing, inspection and culling obtained by 95.83 per cent. Milking was also found one of the major practices followed in dairy unit which was expressed by 93.97 per cent.
\end{abstract}

KEY WORDS : Management practices, Frequency, Percentage, Milk producer, Crossbreed cows, Dairy unit

How to cite this paper : Kolekar, P.L., Gore, N.H. and Lembhe, J.V. (2017). Management practices followed by milk producers in Pune district. Internat. J. Com. \& Bus. Manage, 10(2) : 271-272, DOI: 10.15740/HAS/IJCBM/10.2/271-272. 